\title{
A model for advertising aestheticization: How an ad is aesthetically created and has an impact on audience- product, pdvertising pood and target audience triangle
}

\author{
Recep Yilmaz ${ }^{\mathrm{a}}$, Nurdan Oncel Taskiran, $\mathrm{PhD}^{\mathrm{b}}$ \\ ${ }^{a}$ Beykent University, Istanbul, Turkey. \\ ${ }^{b}$ Assoc. Prof., Kocaeli University, Kocaeli, Turkey
}

\begin{abstract}
Owing to aesthetic components that advertisement texts generally have, advertisements are sometimes perceived as a genre of art by some circles. The study is based upon a perspective presented by an interdisciplinary background and it acknowledges a paradigm that advertising is not a genre of art, it obviously pursues commercial profits and within this context, expolits the created aesthetics in product. The main objective of the study, which focuses advertising aesthetic fundamentally, is to build a scientific model formulating some levels of aestheticisation during its production process. Formulation in question has been reconstructed on theoretical and applied literature.
\end{abstract}

Keywords: Product, Advertising Aesthetics, Target Audience, Advertising Mood, Advertising Text, Aestheticition, Reconstruction

\section{(C) 2013 Published by SSBFNET}

\section{Introduction}

Whether advertising is a sort of art, has been a topic of extended discussion by the academic community and the performers. Some authors concerned with the issue claim that advertising has some similiar common features with artistic genres therefore, advertisements should be evaluated as "artistic works" whereas others oppose. They explicitly focus on the reality that advertisements are merely commercial performances and reject the idea of including them as a part of artistic creation (Venkatesh \& Meamber, 2006; Burgh-Woodman \& Payne, 2012; Rutherford, 1994; Serdarli, 2008). Major reason that lies behind the arguments is mainly the status of craetiveness in advertising business. After the campaign "Think Small", which was realised under the control of William Bernbach in 1959, "creativity" notion was placed in the centre of advertising phenomenon and utilized as its defining fundamental parameter since then. As a consequence, the need for being creative caused an intense involving in aesthetics concurrently. Thus, advertising business achieved a status in the vicinity of art genres. (Sullivan, 1998: 1-14; Yilmaz \& Ertike, 2011: 161). Besides, referring to Hegel (1998) this study acknowledges his theory 'art targets at achieving absolute beauty', but rejects the idea that advertising business participates in it. Consequently, within a pragmatic context it can be mentioned about an instrumentalisation of aesthetic through advertising texts.

Nowadays aesthetic care in advertising texts is so common and has become a usual phenomenon that can be encountered in media easily at all levels. This controlled aestheticisation level is consciously composed by advertising team (Yilmaz \& Ertike, 2011: 46). This study investigates how and in which conditions and ways this aestheticisation is correlated and produced. Within this context, the study objects to find a logical response to this composition and construct a scientific model formulising the level of aeatheticisation within the production process of advertising text. Methodologically, firstly components of aestheticisation are

${ }^{a}$ Corresponding Author, Recep Yilmaz; Tel.: +90 21286753 86; e-mail: recepyilmaz@beykent.edu.tr 
studied, then the model is formulized based on the theoretical and applied litarature. Conclusion part is consisted of an argument about how this model could be utilized by academic world.

\section{Components of Advertising Aesthetics}

Aestheticisation in advertising could be constructed by the coordination of several elements which can be found in advertisements or advertising related works theoretically. In this section of the study, some theoretical reseaches which establish a ground for an aestheticisation model of advertising developed here, is categorized and demonstrated. In the following section, within this context, the relationship among these elements are tried to demonstrate via an illustrated model which we call "aestheticisation model" constructed for the purpose.

\subsection{Advertising Text}

Advertising text is the core, where aestheticisation is achieved. Therefore, it can be assumed as the most essential element of the process. Aestheticisation is developed by means of elements within the text components. In other words, the way they are connected determines the level of the advertising text. In literature, text concept is generally focused on audio visual components rather than literary aspect of an advertisement. By contrast with the concept "copy", which focuses on literary aspect merely, the concept "text" comprises all elements such as image, vocal tone, text, colour, etc. All these elements are determinative for meaning. Grammatical structure is composed by means of these elements. Similar with literary grammar, there is visual grammar to be assumed. It should be considered that literary grammar is only one of the components of the advertisement phenomenon (Schroeder, 2006; Sugarman, 1998; Elden, 2009-b; Serdarli, 2008).

The pattern of meaning and the structure of text of the advertisement evolve as well as the medium diversifies such as printed advertisement materials, radio spots or television commercials. For instance, title of spot in television commercials is not highly regarded, whereas headline of a news paper is the most. Just after Think Small Campaign, especially in press and media, headline has become of vital importance. Necessarily, if headline of an advertisement is not attractive enough, it is almost disregarded. Main text is the part just below the headline. In this part, message is discussed comprehensively. In a television commercial, motion is determinative as well as meaning, image and sound. In this way, each type of advertising constitutes its own grammatical during the process of interaction of its constituents (Applegate, 2004; Cook, 2001; Sugarman, 1998; Rose, 2011). The ways those elements are associated with are determinative of aestheticisation. Generally, the higher the level of aesthetic texts is assumed to be generated through mediation.

\subsection{Institutional Impact}

An advertisement is produced within an institution therefore, expectations of advertiser and institutional expectations are another determiners over the structure of advertising text but, qualifications and form of institutional structure are heterogenious. The institutions in which advertisements are produced are called advertising agency. However, one can not speak of the existence of a monotype agency. There are a great deal of agencies variable from space brokers to the present day organizations. These agencies vary within the context of creative ones as full-service agencies, boutique agencies, modular service agencies or a la carte agencies, house agencies, specialist agencies and rolodex agencies (Elden, 2009-a: 587-609).

In 1960, Marion Harper, who is at the head of Mc Cann Agency, conglomerated Mc Cann under the name of Interpublic; from then on, structures of agencies also underwent changes as well (Tungate, 2007: 14-16). For instance, full service agency performs all marketing activities on behalf of an advertiser whereas boutique agency deals with only creative work. However, to some extent, agencies have certain institutional settlement and all process related to advertising production is constructed within this frame. It includes departments such as administrative, customer care, strategical planning and research, creation, media, transportation/traffic, 
production, administrative and financial business, human resources, marketing and sales development. There are people charged with different responsibilities in each section.

While administative staff is deployed at senior management department, in creative department there are two specialist groups charged with copy scripting and visual design of advertisement. They frequently have meetings to perform advertising process. Such kind of settlement is called matris organizational system. Advertising production process runs like:

When senior manager, strategical planner and costumer representative are employed by an advertiser, customer representative immediately organizes a team from each department (a copy writer, a graphic designer, a trafficer, a producer, a media planner, etc). This team is given the responsibilty of only one assignment each time; for instance, a so called hair shampoo campaign (Balkas and Akbulut, 2006; Mackay, 2005; Monle and Carla, 2005; Richards at all, 2000; Jacobs, 2006; Yeshin, 2006).

Advertising process is performed within an institution like that; as the employment is completed, teams dissolve till the next employment. Ethically, an agency should work for only one brand in the same category, not for the rival firms. This situation is called account conflict. The first thing costumer representatives are instructed is being less tolerant against creative team, because there is an understanding that if they were left to their own devices, they would perform "art". Contraversely, the aim in advertising production does not mean performing art.

The target of art itself is an aesthetical performance. The most essential aim of an advertising campaign is to achieve the anticipated outcomes by the end of the campaign. If the aim is to increase selling percentage to $\% 15$ in the short term, advertiser anticipates the outcomes. A campaign concludes in a real failure if the aestheticisation practice is beyond the understanding level of target audience (Arens, 2006; Balkas and Akbulut, 2006; Brierley, 1995; Gulsoy, 2012; Kaynak at all, 1994). Therefore, aestheticisity of an advertisement must be balanced accordingly.

\subsection{Advertising Channels}

The environment in which advertisement is broadcasted or printed is called Advertising Channel. Capability of it also determines the boundaries of advertising aestheticisation. Within this frame, it would be beneficiary to investigate advertising environment and qualifications comparatively and the ways it makes human mind work. Advertising Channels can be classified into eight groups: broadcasting channels (radio, television), printed channels (newspaper and magazines), direct posting or via other printed materials, outdoors, transit channels, via internet, Point of Purchase (P.O.P), cinema and alternative channels. The first channel is radio and television. In radio broadcasting there are four types of advertising; spots and public announcements, musical and dramatical advertising, programmed advertising, special promotional advertising.

In television broadcasting there are eight types of advertising; still advertising, moving advertising, special promotional advertising, scrolling/banner advertising, advertorials, in-programme promotional advertising, product placement in serials, product placement in programmes. Major advertising channels of printed materials are mainly divided into three: press, magazines and direct posting. Types of advertisements that take place in press are display advertising, classifieds, public announcements and inserts. Direct posting types of advertising include letters, booklets, sheets, pamphlets, fliers, leaflets, catalogues. Types of open air advertising are billboards, posters, placards, illuminated announcements, mega boards, Wall and roof advertisments, stop ads, ground and window graphics for external and internal environments, excavations and home boards (Elden, 2009-a: 213-276).

Transit advertising channels and the internet have completely different types of advertisements; banners, border frames, popping up boxes, rich media, screen savers, profile advertisements, content sponsoring, advertorials model, affilate programmes, sibling windows, push, impression, targeted advertising, searching engine advertisements and classifieds. Point of purchase (POP) applications and cinema are other alternatives of advertising channels. In cinema films, there are three types of product placements: screen placement, script 
placement and plot placement. Moreover, adpeople, surprise eggs, advergames are other channels to publicize products curiously by advertising agencies. Common point of all these advertising channels is that of being related to mass. However, considering their way of presentation as a device, it is observed that advertising channels differentiate each other.

Channels like television, radio and cinema, address to a relatively expansive audience. and all messages are moving. Radio is merely an aural device, whereas the other two submit audio and visual together. Cinema, being an audio- visual device, addresses to a limited number of audience in relation to television channel. Therefore, meeting point of two audiences differentiates, as well. Cinema audience is more focused than televison audience, considering the way of they involve. Television audience is not lucky enough; there are a great deal of distracting factors nearby. The internet is an interactive device therefore, it is completely different. Printed advertising channels presents only visuals, however, its effectiveness would be higher, depending upon the concentration of audience to the channel or intelligency of the advertising. Outdoors are quite different, considering the way of interaction with audience. The most important feature of these advertising channels is the way consumer encounters with ads. Its environmental background functions here essentially and creates a distinctive atmosphere. Transit advertising channels are mostly vehicles; buses, taxis, trains etc. An advertising text on a bus would affect consumers in a different way therefore, the way it accesses to the consumer and the way of interaction would be rather effective. POP channels are mostly functional from purchasing point of view, because they are placed in very crowded malls where people seek to purchase. As shown explicitly, advertising channels, related to the features of device, make human minds work in different ways so that, it determines human reception. Advertising creatives devise effective strategies for tool-mind interactivity in each channel. The only stable thing is, along with the advantages, tool restriction of human mind a bit more. However, from the tool-mind dialectic point of view, advertising mood determines the way of advertising aestheticisation is explicitly accurate (Basal, 1998; Sissors and Baron, 2002; Demiray at all, 2011; Postman, 2005; Taskiran and Yilmaz, 2007; Zwick \& Dholakia, 2006).

\subsection{Qualifications of Product}

Advertising is a sort of reproduction process business. Within the process, what is reproduced is the reality itself. Advertising text is a copy of a product; in other words, advertising is a type of representation. Quality of this representation is closely related to the specifications of a product and the market it is placed and the brandname's position in the market. All these elements deeply affect the way aestheticisation is produced. Designing, utility and interpretation of message by target audience are constituing elements of product qualifications. The more qualified the product, the easier it gets to produce a reproduction of it. It is also crucial in eastheticisation production. In the same way, the market in which a product is marketed and the situation of the brandname in this market are also determinative for a product. As creatives determine a strategy for an advertisement they consider the product, its reality as well as the market and the situation of the brand in it. For a product in a monopolic market there would be no rivals, therefore, when using generic strategy, advertising text could be constructed on a hard sell basis accordingly. As direct presentation encircles the advertisement, aestheticisation level declines accordingly. If there are plenty of brandnames in the market and they have similar specifications in common this situation also affect advertising text definitely. Some categories including similar products such as water or hair shampoo, preemtive stategy is obliged. It means keeping the product away from the rivals compulsorily and make the product unlike the others. This situation would require a softsell dealing on the advertising team but, aestheticisational elevation could be achieved in return (Chioveanu, 2008; Wernick, 1991).

\subsection{Aesthetical Acclaim Level of Target Audience}

Aesthetical appreciation level is a significant element in advertising business. Aesthetical appreciation level of mass audience and the advertising level of aestheticisation is proportional. The most determinative parameter here is the culture of the mass audience. The sub-culture they belong to, their educational level and religious doctrines determine their way of life and level of their minds from receptional point of view. If target audience is conservative and literal skills are undeveloped, an advertising text with high mediation and sexual components would be inappropiate. Accordingly, for an intelligent mass an advertising text with low 
mediation would cause an irritation. This is mostly related to target audience the product addresses. What significant here is characteristics of the target audience, more than the product specifications. This level is submitted to the advertising agency beforehand. In case the levels disagree campaign concludes in total failure (Eisenbeis, 1980; Wells, 1994).

\section{Model}

The subject matter-Aestheticisation model- is illustrated below;

Figure 1

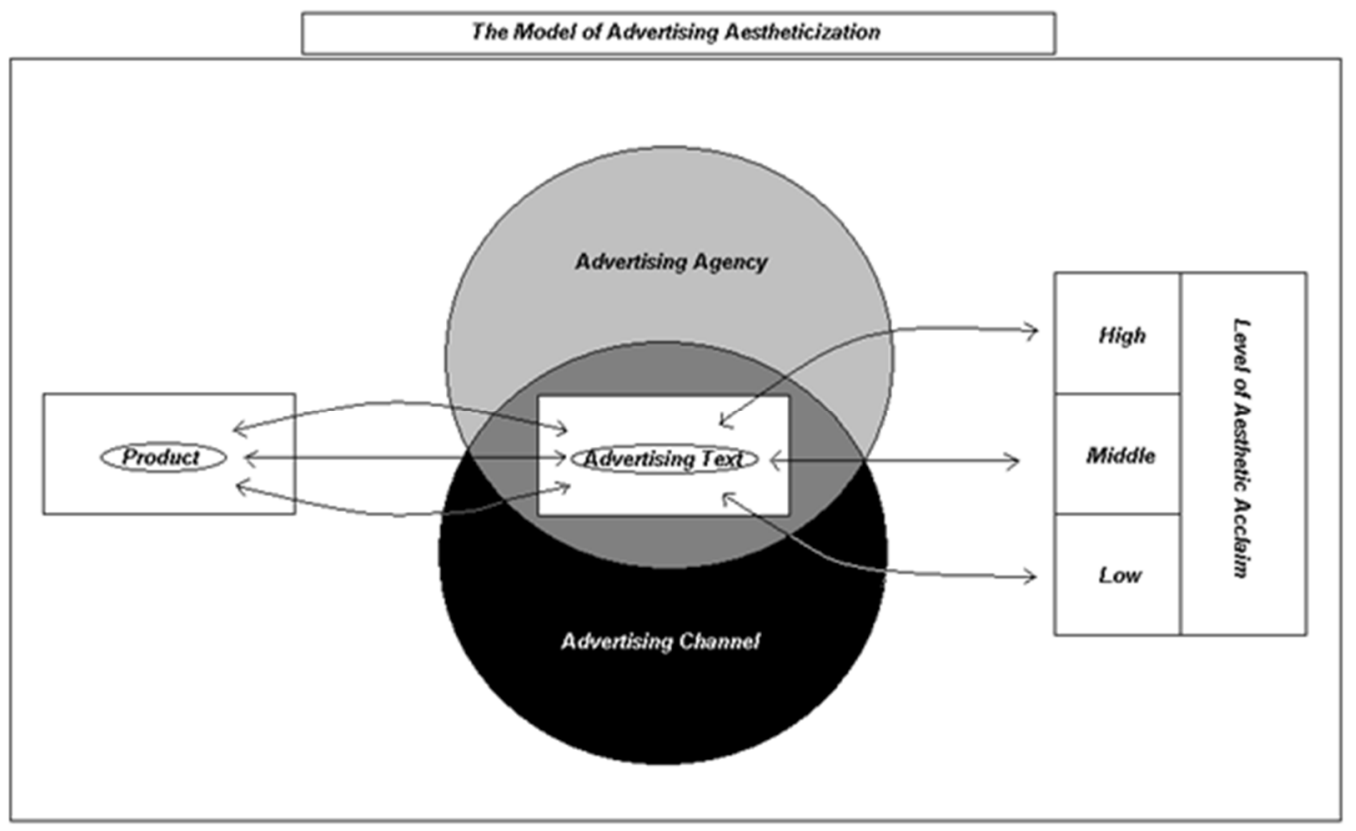

As shown in figurel advertising text is placed in the centre of the model because it is the place where aestheticisation process is assumed to be initiated. As it can be seen in the model illustration, the text in the centre is intersected by two circles; one of which represents the advertising institution while the other represents the media by which the advertising process is publicised.

Institutional characteristics and formation, structural features of advertising media, its advantages and restrictions are the major factors that affect the process of textual formation fundamentally. This situation determines textual aestheticisation of the text. Another essential point is the qualities of the product; what determines the product in the market is its environment, the way it is developed and its structural characteristics.

As pointed out in previous paragraphs, graphical text of the advertisement is a kind of reproduction of the product itself. Within this context, advertising creative staff take into consideration the product itself when they determine a strategy for it. For instance, for a product in a monopolic market there would be no challenging, therefore, when using generic strategy, advertising text could be constructed on a hard sell basis accordingly, but it would cause an aestheticisational decline. Some categories including qualified products such as hair shampoo or water, preemtive stategy is obliged, therefore, diversification of the product should be considered, as well. This situation would impose a softsell dealing on the advertising team but, aestheticisational elevation could be achieved in return. Another determinative element is aestheticisational level of the advertising text which is determined by the aesthetic level of appreciation of target audience. It is directly related to their cultural background. 
Elements such as sub-culture they belong to, their educational level and religious belief determine their philosophy of life and receptional level of their minds. For instance, for a conservative taget audience, whose literal skills are undeveloped, a text with high mediation and sexual components would be repulsive. Accordingly, for an intelligent mass who experienced postmodern culture, a text with low mediation would cause an irritation. This is acceptable for the brandnames within the same category. What essential here is characteristics of the taget audience, more than the product specifications. As mentioned above, the environment in which advertising text is to be published or broadcasted is determinative as well. Depending upon the environmental characteristics, instrumental features drives human mind run in different ways so that it determines reception. For instance, radio as a medium, employs imagination but deprives people of visual opportunity whereas television provides people with aurality and visuality at the same time, but reduces human mind to a submissive state. Although advertising creatives employ particular strategies for each advertisement, creativeness is limited on various ways. Within this context, advertising mood determines the aestheticisational manner.

This situation during the campaign could be accomplished by the coordination of several environments and sometimes causes more potential statements. However, what to be noticed here is, the model construction of the advertisement must be based on single advertisement texts. Another essentiality with the model is emerging of the aestheticisation level during the above mentioned whole process. In other words, specifications of product, advertising mood and aesthetic level of appreciation of mass audience, as parameters of the same significance, determine the aesthetitical level of an advertisement

\section{Conclusion}

Models are some types of molds presented to scholars. A model suggests an explicit idea on the subject matter, which is also the main apprehension of the modelist. Here we tried to produce a model on advertising aestheticisation relating to advertising text and target audience and how it is produced. Although we based on a paradigm literally, the model cannot be claimed as perfect. As a result of reactions and suggestions, we probably develop this study further, or, somebody else can; or completely opposite studies will appear on the issue. From advertisement- art discussion point of view, we hope it is comprehensible enough and suggests the idea evidently.

\section{References}

Applegate, E. (2004). Strategic Copywriting. USA: Rowman \& Littlefield Publications.

Arens, W. F. (2006). Contemporary Advertising. Boston: Mcgraw-Hill Publications.

Balkaş, E. E. ve N. T. Akbulut (2006). Adım Adım Reklâm Üretimi [Advertising Production: Step by Step]. İstanbul: Beta Publications.

Basal, B. (1998). Medya Planlaması [Media Planning]. İstanbul: Cantay Publications.

Brierley, S. (1995). The Advertising Handbook. London: Routledge Publications.

Burgh-Woodman, H. \& Payne, C. (2012). Consuming the Aesthetic of the Everyday: A Visual Analysis of Errol Morris' High Life, Asia-Pacific Advances in Consumer Research 9: 1-23.

Chioveanu, I. (2008). Advertising, Brand Loyalty and Pricing, Games and Economic Behavior 64 (1): 68-80.

Cook, G. W. D. (2001). The Discourse of Advertising. London: Routledge Publications.

Demiray, U., N. O. Taşkıran ve R. Yilmaz (2011). Meta Communication Concept and the Role of Mass Media in Knowledge Building Process for Distance Education, Meta-Communication for Reflective Online Conversations: Models for Distance Education. (pp. 249-264). eds. U. Demiray, T. V. Yüzer ve G. Kurubacak. USA: IGI Global Publications.

Eisenbeis, M. (1980). Visual Design of Information Systems, Displays 2(2): 95-99.

Elden, M. (2009-a). Reklâm ve Reklâmcllık [Advertisement and Advertising]. İstanbul: Say Publications.

Elden, M. (2009-b). Reklâm Yazarlı̆̆ [Copywriting]. İstanbul: İletişim Publications.

Gulsoy, T. (2012). Managing a Strategic Business Relationship in an Emerging Market: Advertising Agency-Client Relationships in Turkey, Procedia - Social and Behavioral Sciences 58: 1386-1394.

Hegel, G. W. F. (1998). Aesthetics: Lectures on Fine Art, Volume 1. New York: Oxford University Press.

Jacobs, H. (2006). Advertising. Australia: Career FAQs Publications. 
Kaynak, E., O. Kucukemiroglu and Y. Odabasi (1994). Advertising Agency/Client Relationships in an Advanced Developing Country, European Journal of Marketing 28(1): 35-55.

Mackay, A. (2005). The Practise of Advertising. England: Butterworth-Heinemann Publications.

Monle, L. and J. Carla (2005). Principles of Advertising. England: The Haworth Press.

Postman, N. (2005). Amusing Ourselves to Death: Public Discourse in the Age of Show Business. USA: Penguin Books. Richards, B., I. Macrury ve J. Botterill (2000). The Dynamics of Advertising. England: Taylor\& Francis Publications.

Rose, G. (2011).Visual Methodologies: An Introduction to Researching with Visual Materials. USA: Sage Publications.

Rudherford, P. (1994). The New Icons: The Art of Television Advertising. Toronto: University of Toronto Press.

Schroeder, J. (2006). Editorial: Introduction to the Special Issue on Aesthetics, Images and Vision, Marketing Theory 6(1): 5-10.

Serdarli, E. (2008). Reklâm Yazmak [Copywriting]. İstanbul: Beta Publications.

Sissors, J. S. ve R. B. Baron (2002). Advertising Media Planning. Boston: Mcgraw-Hill Publications.

Sugarman, J. (1998). Advertising Secrets of the Written Word: The Ultimate Resource on How to Write Powerful Advertising Copy from One of America's Top Copywriters and Mail Order Entrepreneurs. USA: Delstar Publications.

Sullivan, L. (1998). Hey, Whipple, Squeeze This: The Classic Guide to Creating Great Ads. USA: John Viley \& Sons Publications.

Taskiran, N. O. ve R. Yilmaz (2007). İnsan Gerçekliği ve Medya: Gerçekliğin Yapısında Medyanın İşlevsel Konumu Üzerine Bir Çözümleme [Human Reality and Media], Medya Eleştirileri: Gerçeğin Dışındakiler. (pp. 9-37). eds. C. Bilgili ve N. T. Akbulut. İstanbul: Beta Publications.

Tungate, M. (2007). Adland: A Global History of Advertising. London: Cogan Page Publications.

Venkatesh, A. \& Meamber, L. (2006). Arts and Aesthetics: Marketing and Cultural Production, Marketing Theory 6(1): 11-39.

Wells, J. A. (1994). Readability of HIV/AIDS Educational Materials: The Role of the Medium of Communication, Target Audience, and Producer Characteristics, Patient Education and Counseling 24(3): 249-259.

Wernick, A. (1991). Promotional Culture: Advertising, Ideology and Symbolic Expression. USA: Sage Publications.

Yeshin, T. (2006). Advertising. Londra: Thomson Learning Yayınları.

Yilmaz, R. \& Ertike, A. S. (2011). Reklamcılı̆̆ın Anahtar Kavramları [Keywords in Advertising]. İstanbul: Kitabevi Publications.

Zwick, D. \& Dholakia, N. (2006). Bringing the Market to Life: Screen Aesthetics and the Epistemic Consumption Object, Marketing Theory 6(1): 41-62. 